\title{
Purification, Amino Acid Sequencing and Thermostability of an Extracellular Low Molecular Weight Esterase Produced by Bacillus Subtilis NRRL 41270 in Fermentation \\ Papagianni $\mathbf{M}^{1 *}$ and Papamichael EM ${ }^{2}$
}

${ }^{1}$ Department of Hygiene and Technology of Food of Animal Origin, School of Veterinary Medicine, Aristotle University of Thessaloniki, Greece ${ }^{2}$ Department of Chemistry, University of Ionnina, Ioannina, Greece

\begin{abstract}
Extracellular esterase activity in Bacillus subtilis NRRL 41270 fermentation broths was found to reside in a small protein with a molecular weight less than $10 \mathrm{kDa}$. Following purification, esterase activity on fluorescein dibutyrate was estimated at $12 \mathrm{U} / \mathrm{min} / \mathrm{mg}$ proteins. Enzyme saturation was observed at $5 \mu \mathrm{M}$ substrate concentration. The produced esterase hydrolysed tributyrin. Its specific activity was estimated to be $17.8 \mu \mathrm{mol}$ acid released $/ \mathrm{min} / \mathrm{mg}$ proteins. The small protein was subjected to size exclusion chromatography, SDS-PAGE and amino acid sequencing. Analysis revealed a sequence of the following amino acid residues: eevaetysfyhitphdystshispapvqffspap, according to which the molecule has 34 amino acid residues and a calculated molecular mass of 3853, which was in accordance with the gel filtration and SDS-PAGE results. Sequence based analysis and use of bioinformatics tools showed no significant similarity with known proteins while revealed a strongly hydrophobic molecule, with a $\alpha$-helical conformation in the $\mathrm{N}$-terminal, the rest of the molecule being $\beta$-sheet-rich. The enzyme appeared to be thermostable with more than $85 \%$ of the original activity maintained after $120 \mathrm{~h}$ incubation at $60^{\circ} \mathrm{C}$. The producer organism and the features of the micro enzyme, suggest the case of a biotechnologically interesting biocatalyst that should be further researched in terms of its stability and production characteristics.
\end{abstract}

Keywords: Bacillus subtilis; Esterase; Micro enzyme; Purification; Sequence

\section{Introduction}

Bulk production of industrial enzymes, e.g. proteases, lipases, amylases and others, is mainly through fermentation with Gram-positive bacteria and fungi. Certain Bacillus species are regarded as important microbial cell factories. The capacity of selected strains of B. subtilis, $B$. licheniformis and others, to produce and secrete large quantities (20-25 $\mathrm{g} / \mathrm{L}$ ) of extracellular enzymes (proteases, lipases, amylases, esterases) has placed them among the most important industrial enzyme producers $[1,2]$.

B. subtilis has attracted early research interest on various aspects of its physiology, production and applications, and it is the bestcharacterized among Bacillus species. The early sequencing of $B$. subtilis genome and extensive proteome analysis generated knowledge through the years so that the particular organism provided an excellent model in Systems Biological studies [1]. Since most of B. subtilis applications are related to the high-level secretion of proteins, major research has been focused on the cell factory's secretion machinery $[1,3,4]$.

As a natively soil bacterium, $B$. subtilis secretes numerous enzymes to degrade a variety of substrates, enabling the bacterium to survive in a continuously changing environment [5]. Several B. subtilis strains are known as excellent producers of proteases and lipases in submerged and solid-state fermentation. These enzymes are produced commercially and their production represents the major part of the industrial-enzyme market. A relatively large number of proteases, lipases and esterases produced by $B$. subtilis species have been purified, characterized biochemically and their fermentation conditions optimized for maximum yields. A common limitation of industrial application of lipases and esterases is their limited thermostability at high temperatures, as well as the limited $\mathrm{pH}$ stability in operating industrial conditions. Therefore, searching for novel microbial enzyme sources is of great importance in the development of new thermostable enzymes and subsequent applications. Several thermostable esterases have been reported from Bacillus species, including B. stearophilus, B. subtilis, B. licheniformis S-86 and Bacillus sp. RN2 and B. cereus [6-10].
In this work, we report the purification procedure, amino acid sequence and thermostability profile of a low molecular weight enzyme (micro enzyme) with esterase activity in B. subtillis fermentation broths. Esterases (carboxylic ester hydrolases) constitute a large group of enzymes that catalyze the hydrolysis, synthesis or trans esterification of ester bonds. They are found in all forms of life, including the group of hyper thermophilic bacteria and archaea. The molecular mass of esterases is usually in the range of $20-160 \mathrm{kDa}$ [11]. Esterases with lower molecular masses exist but reports are rather rare and the information given is limited [12]. The full sequence of an esterase of 118 amino acids and molecular mass $13.72 \mathrm{kDa}$ produced by a $B$. thuringiensis strain was reported in GenBank (AHZ51904.1) [13]. Simoes et al. described a thermostable esterase of $1.57 \mathrm{kDa}$ produced by B. stearothermophilus NCIMB $13335[11,14]$. Other reported micro enzymes include a 5.7 $\mathrm{kDa}$ esterase by Candida lipolytica, a $9.7 \mathrm{kDa}$ rennin by an unclassified Actinomycete, a disulfide bond-forming enzyme of $6.2 \mathrm{kDa}$ produced by the archaebacterium Sulfoborus solfataricus, an $8 \mathrm{kDa}$ protease by the extremophilic bacterium Kurthia spiroforme [15-18]. Three more micro enzymes (1.53, 1.827 and $4.275 \mathrm{kDa})$ with esterase activity produced by the thermophilic filamentous fungi Talaromyces emersonii and Emericella nidulans were reported by Xiaolin and Mattey [19]. None of these peptide biocatalysts however, has been characterized in terms of their structural features, e.g. amino acid sequence and primary structure and therefore critical analysis is restricted. Also, in most cases

*Corresponding author: Maria P, Department of Hygiene and Technology of Food of Animal Origin, School of Veterinary Medicine, Aristotle University of Thessaloniki, Greece, Tel: 302310999804; Fax: 302310 999829; E-mail: mp2000@vet.auth.gr

Received May 26, 2017; Accepted June 03, 2017; Published June 10, 2017

Citation: Maria P, Emmanuel MP (2017) Purification, Amino Acid Sequencing and Thermostability of an Extracellular Low Molecular Weight Esterase Produced by Bacillus subtilis Nrrl 41270 in Fermentation. J Microb Biochem Technol 9:117-121. doi: 10.4172/1948-5948.1000353

Copyright: (c) 2017 Maria P, et al. This is an open-access article distributed under the terms of the Creative Commons Attribution License, which permits unrestricted use, distribution, and reproduction in any medium, provided the original author and source are credited. 
important information on properties that determine the enzyme-like character, e.g. substrate specificity, heat denaturation or $\mathrm{pH}$ profile, is not provided. The present work aims to provide substantial information on the isolated biocatalyst with esterase activity.

\section{Materials and Methods}

\section{Microorganisms and culture conditions}

Storage: Glycerol stocks of two independent clones of B. subtilis NRRL 41270 were maintained at $-80^{\circ} \mathrm{C}(1.3 \mathrm{ml}$ fresh overnight culture $+50 \%$ glycerol). Long-term storage for frequent use was by means of plating on nutrient sporulation medium (NSM; $0.8 \%$ nutrient broth (Sigma-Aldrich), $0.05 \mathrm{mM} \mathrm{MnCl}, 0.7 \mathrm{mM} \mathrm{CaCl}_{2}$, and $1.0 \mathrm{mM}$ $\mathrm{MgCl}_{2}$ ). For frequent use, B. subtilis was grown on Luria-Bertani agar plates at room temperature (LB agar plates: LB broth [tryptone, $10 \mathrm{~g} / \mathrm{l}$; yeast extract, $5 \mathrm{~g} / \mathrm{l} ; \mathrm{NaCl}, 10 \mathrm{~g} / \mathrm{l}]+$ technical agar, $15 \mathrm{~g} / \mathrm{l}$ ).

Growth conditions: A loop full of stock culture was plated out on LB agar containing $0.4 \%$ tributyrin and inbubated at $37^{\circ} \mathrm{C}$. Twenty four hours later, colonies exhibiting clear zones were inoculated individually into $250 \mathrm{ml}$ Erlenmeyer flasks containing $25 \mathrm{ml}$ of LB broth and shaken at $100 \mathrm{rpm}$ for $24 \mathrm{~h}$ at $37^{\circ} \mathrm{C}$. For esterase production, $5 \mathrm{ml}$ of LB broth culture were inoculated into $500 \mathrm{ml}$ of fermentation medium and placed in a BIOFLO 110 New Brunswick Scientific stirred tank bioreactor (STR) with a working volume of 21 , at $37^{\circ} \mathrm{C}$ for 24 $\mathrm{h}$ with aeration. The agitation system of the reactor was consisted of two 6-bladed Rushton-type impellers $(52 \mathrm{~mm})$, operated at the stirrer speed of $100 \mathrm{rpm}$. The temperature was maintained at $37^{\circ} \mathrm{C}$. The air flow rate was $1 \mathrm{vvm}$. The oxygen sensor was calibrated by sparging the medium with air (dissolved oxygen tension, DOT 100\%) and $\mathrm{N}_{2}$ (DOT $0 \%)$. Following sterilization $\left(120^{\circ} \mathrm{C} / 15 \mathrm{~min}\right)$, the $\mathrm{pH}$ of the medium was adjusted with titrants ( $1 \mathrm{M} \mathrm{NaOH}$ and $\mathrm{HCl}$ solutions) at the chosen level of $\mathrm{pH} 7.0$ and remained under control during fermentation by automatic addition of titrants.

The fermentation medium contained the following: D-glucose, $5 \mathrm{~g} / \mathrm{l}$; glycerol tributyrate, $4 \mathrm{~g} / \mathrm{l} ; \mathrm{MgSO}_{4} .7 \mathrm{H}_{2} \mathrm{O}, 0.5 \mathrm{~g} / \mathrm{l} ; \mathrm{KCl}, 0.5 \mathrm{~g} / \mathrm{l}$; $\mathrm{FeSO}_{4} .7 \mathrm{H}_{2} \mathrm{O}, 0.001 \mathrm{~g} / 1$; ammonium acetate, $5 \mathrm{~g} / 1$; phosphate buffer, $0.04 \mathrm{M}, \mathrm{pH}$ 7.0. An amino acids supplement was prepared and added to the above medium at the final concentration of $150 \mu \mathrm{M}$. The supplement contained the following (final concentration): Casamino Acids (Difco 0230-15-5), 4 g/1; L-glutamine (Sigma G8540), 0.1 g/l; L-tryptophan (Sigma T0254); 0.1 g/1; L-asparagine (Sigma 0884), 0.02 g/l; L-methionine (Sigma M9625), $0.02 \mathrm{~g} / 1$.

Fermentation was interrupted at $24 \mathrm{~h}$ from inoculation, when the level of enzyme activity was maximal. Samples were withdrawn at regular time intervals from the fermentation broth for analyses. The course of growth was monitored by measuring the absorbance at 580 $\mathrm{nm}$ using a BioMate 3S UV-Visible spectrophotometer (ThermoFisher Scientific). Esterase activity was determined by a fluorimetric assay after the cells and tributyrin were removed.

Purification of esterase: Cells were removed from the fermentation broth by centrifugation at $15,000 \mathrm{x}$ g for $15 \mathrm{~min}$ at $4^{\circ} \mathrm{C}$. To remove excess tributyrin, the supernatant was filtered through Whatman No. 1 paper. The filtrate was passed through a tangential flow filtration (TFF) device (Mini-Ultracette, Pall Filtron) with a cut-off of $10 \mathrm{kDa}$. The filtrate was loaded on to a $1 \times 100$ Bio-Gel P-6 column (Bio-Rad) for size exclusion chromatography. Pre-equilibration of the column was done with $100 \mathrm{mM}$ ammonium bicarbonate at $\mathrm{pH} 7.5$ and elution with the same buffer at the flow rate of $0.08 \mathrm{ml} / \mathrm{min}$. Fractions of 1 $\mathrm{ml}$ were examined for esterase activity and protein content. Protein concentration was measured with the ninhydrin reaction in which 0.1 $\mathrm{ml}$ of each fraction was mixed with $0.9 \mathrm{ml}$ of $0.2 \%$ ninhydrin solution in ethanol and the absorbance was monitored at $540 \mathrm{~nm}$. Positive samples were dehydrated using a centrifuge concentrator (5305 Eppendorf) and analyzed by HPLC using a Hamilton PRP-3 reverse-phase column (2.5 $\times 150 \mathrm{~mm}, 10 \mu \mathrm{l}, 300 \AA$, Hamilton Company).

Enzyme assays: Esterase activity in the filtrates was measured by the fluorimetric assay described by Kramer and Guilbault [20] and Guilbault and Kramer [21]. Fluorescein dibutyrate was used as substrate at the concentration of $5 \times 10^{-6} \mathrm{M}$. The substrate was prepared by emulsifying $10 \mathrm{~g}$ of tributyrin in $90 \mathrm{ml}$ of $10 \%$ acacia gum solution. $0.5 \mathrm{ml}$ substrate and $0.5 \mathrm{ml}$ of $0.1 \mathrm{M}$ phosphate buffer $(\mathrm{pH} 7.5)$ were added to $1 \mathrm{ml}$ of sample and the mixture was incubated at $40^{\circ} \mathrm{C}$ for $2 \mathrm{~h}$ in a shaking water bath. The reaction was terminated by adding $10 \mathrm{ml}$ of an acetone:ethanol 1:1 mixture. The liberated from the reaction butyric acid was determined by titration with $1 \mathrm{M} \mathrm{NaOH}$.

Estimation of protein content: Protein concentration in the samples was determined by following the protocol of Lowry et al, using Folin phenol as coloring reagent and bovine serum albumin (BSA) as the standard. Absorbance was monitored at $660 \mathrm{~nm}$ [22].

Molecular mass determination: The samples derived from size exclusion chromatography were desalted by dialysis using a mini dialysis kit with $1 \mathrm{kDa}$ cut off (GE Healthcare Life Sciences) and then were dehydrated at a centrifuge concentrator to concentrate the enzyme. The concentrates were re-suspended in distilled water and loaded on two $17 \%$ polyacrylamide gels in a discontinuous buffer system lacking SDS (non-denaturing) which was run in parallel. One of the gels was stained with a silver stain (Invitrogen) while the other was stained for esterase activity. The gels, processed for esterase localization were incubated in a reaction mixture containing naphthyl acetate $(5.58$ $\times 10^{-3} \mathrm{mM}, \mathrm{pH} 7.5$ ) and $0.04 \mathrm{~g}$ Fast Blue $\mathrm{RR}$ at $25^{\circ} \mathrm{C}$ for $1 \mathrm{~h}$. Upon development of the dark brown bands, indicating esterase activity, the reaction was terminated by fixing the gel in $7 \%(\mathrm{v} / \mathrm{v})$ glacial acetic acid for $20 \mathrm{~min}$, followed by preservation of the gel in $5 \%(\mathrm{v} / \mathrm{v})$ acetic acid prepared in $10 \%$ methanol.

The recovered from native-PAGE gels protein was subjected to discontinuous SDS-PAGE, using the Laemmli buffer system with $16.5 \%$ acrylamide and $6 \%$ bisacrylamide slab gels. Silver staining was applied. The molecular mass of the protein was roughly estimated using a protein ladder of 1.7 to $40 \mathrm{kDa}$ as molecular weight markers (Thermo Scientific).

Amino acid analysis: For determination of the amino acid sequence, the protein sample was transferred from SDS-PAGE gel onto a polyvinylidene (PVDF) membrane by western blotting and the membrane carrying the protein was subjected to sequencing [23]. Amino acid sequence was determined by Edman degradation sequencing of the protein using an Applied Biosystems Procise Sequenser (ABI 494 protein sequencer).

Determination of thermostability: The stability of pure enzyme in solution was examined at $40,50,60,70,80$ and $90^{\circ} \mathrm{C}$. Enzyme solutions were prepared at the concentration of $0.1 \mathrm{mg} / \mathrm{ml}$ in $20 \mathrm{mM}$ Tris- $\mathrm{HCl}$ buffer, $\mathrm{pH}$ 7.5. Twice a day, samples were removed from the incubators, left to cool at ambient temperature and freezed. Incubation lasted 120 h. Samples were assayed for esterase activity. Activities were expressed as percentages of the activity at the starting point (time 0 ).

Sequence-based analysis and bioinformatics tools: The software Clone Manager 7 (version 7.11, Sci Ed Central) was used for sequence- 
based computation analyses. The following analyses were performed: Molecular weight, isoelectric point, amino acid composition profile, three-line graphs plots for the predicted values for $\alpha$-helix, $\beta$-sheet and $\beta$-turn configurations, hydrophilicity analysis and plots according to Kyte and Doolittle [25], Hopp and Woods [26] and surface exposure analysis according to Janin et al. [27]. Homology searches were performed with BLAST (Basic Local Alignment Search Tool, NCBIalgorithm blastP).

\section{Results and Discussion}

Bacillus subtilis NRRL 41270 was cultivated for $24 \mathrm{~h}$ at $30^{\circ} \mathrm{C}$ and 100 rpm under full aeration, in a stirred tank bioreactor (batch culture). The fermentation medium contained tributyrin and a low concentration of glucose (Figure 1). Figure 1 shows the results of absorbance monitoring of growth and esterase activity. Maximum absorbance readings were obtained between 14-16 h of fermentation while they started decreasing from $18 \mathrm{~h}$ onward. Maximum esterase activity was obtained with $21 \mathrm{~h}$ samples of fermentation broth. Cells and excess tributyrin were removed from these samples and the filtrate was separated into fractions of less and more than $10 \mathrm{kDa}$. Esterase activity was detected only in the $<10 \mathrm{kDa}$ filtrates following filtration through the tangential flow filter as described in the previous section. The Bio-Gel P-6 resolved peptides in the range of 1.1 to $5.7 \mathrm{kDa}$. Size exclusion chromatography of the filtrates gave one peak of esterase activity in the range of fractions 70 to 75 (Figure 2). Low molecular weight esterase activity increased during fermentation from nil to $35 \mathrm{U} / \mathrm{min} / \mathrm{ml}$ at $13 \mathrm{~h}$ of cultivation, to $52 \mathrm{U} / \mathrm{min} / \mathrm{ml}$ at $21 \mathrm{~h}$.

Following purification, esterase activity on the fluorescein dibutyrate substrate was estimated to be $12 \mathrm{U} / \mathrm{min} / \mathrm{mg}$ proteins. Enzyme saturation was observed at the substrate concentration of 5 $\mu \mathrm{M}$. The produced esterase hydrolysed tributyrin. The specific activity of the enzyme using the titration assay with $1 \mathrm{M} \mathrm{NaOH}$ was $17.8 \mu \mathrm{mol}$ acid released $/ \mathrm{min} / \mathrm{mg}$ proteins. The results therefore show the presence

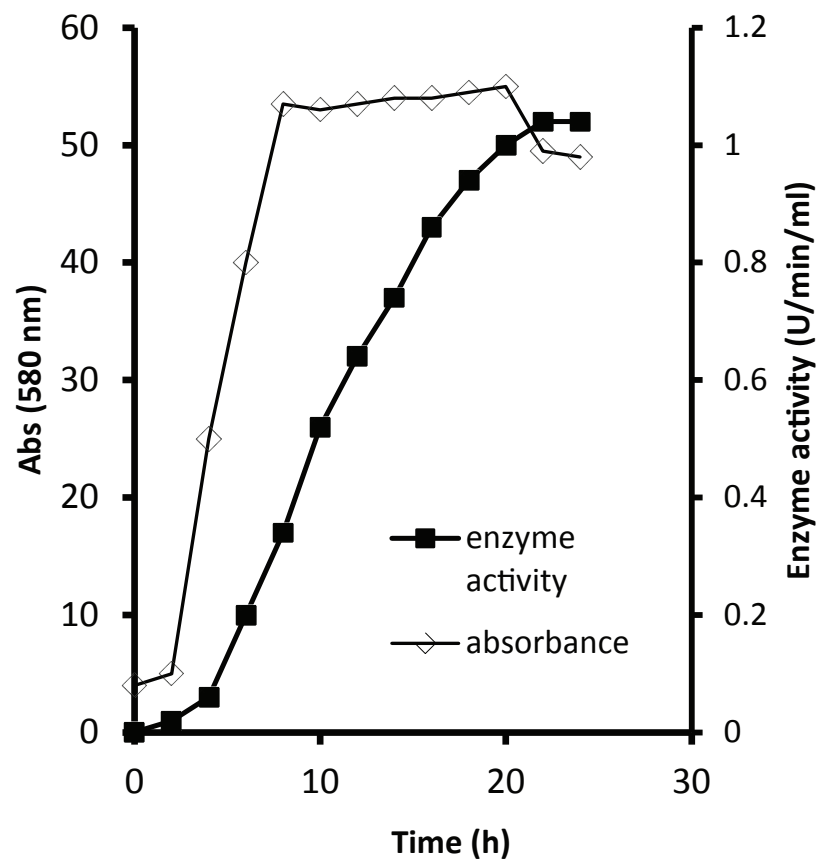

Figure 1: Time-courses of growth (absorbance monitoring) and esterase production in B. subtilis NCIMB 8054 fermentation.

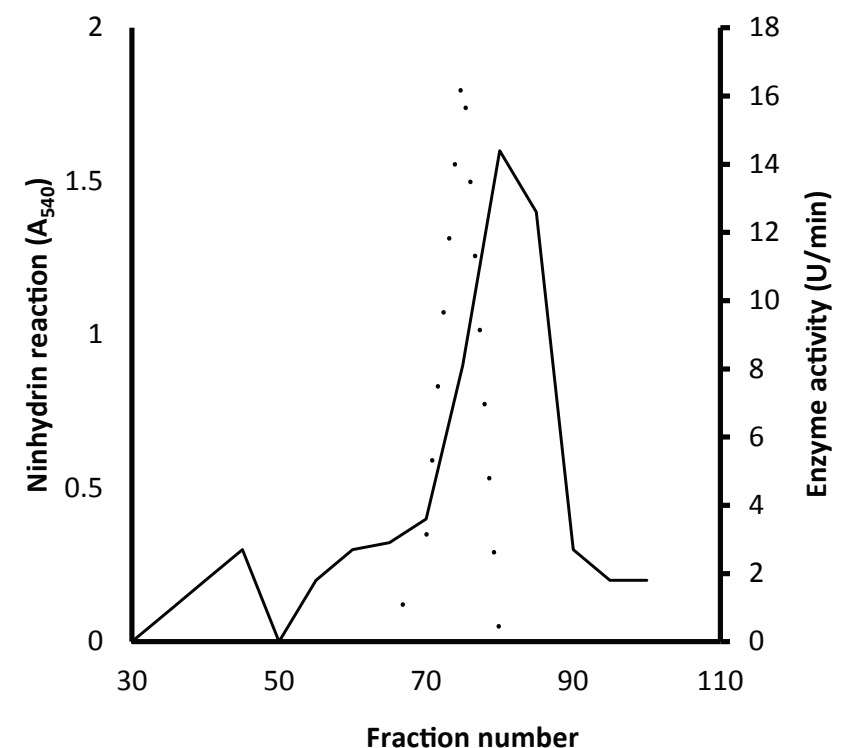

Figure 2: Elution profile of the $<10 \mathrm{kDa}$ filtrate from a Bio-gel P-6 column affinity chromatography. Solid line: ninhydrin reaction; Dashed line: esterase activity.

of an enzyme that catalyzes the hydrolysis of esters. Native PAGE was carried out using both silver and esterase activity stain as described in the previous section, and confirmed that esterase activity was due to the detected protein.

The approximate molecular weight of the enzyme was determined by SDS-PAGE. A band was obtained, similar to those of the native gel, with a molecular weight of about $3.8 \mathrm{kDa}$ (Figure 3). Amino acid sequence analysis gave the following results: eevaetysfyhitphdystshispapvqffspap. The small protein molecule has 34 amino acid residues and according to the derived composition the calculated molecular mass is 3853.1 (Table 1). Table 1 shows the number and percentage composition of the identified 34 amino acids. The calculated isolectric point for the protein is 4.58 . There is a high content in serine and proline, 5 residues each or $14.7 \%$. A very low content of $2.9 \%$ (representing 1 amino acid) has been found for glycine and aspartate. A general BLAST (program BLASTP 2.2.24+) search carried out for the particular sequence of the esterase revealed no significant similarity with other deposited proteins or peptides.

Primary structure analysis was carried out using the Kyte and Doolittle [25], Hope and Woods [26] and Janin et al. [27] routines to determine the hydrophilic/hydrophobic profile of the protein, while according to Garnier et al. [24] for prediction of $\alpha$-helix, $\beta$-sheet and $\beta$-turn configurations [28-30] (Figures 4 and 5). According to the generated data, the $B$. subtilis esterase appears to be strongly hydrophobic, with more than $80 \%$ of its amino acid residues being hydrophobic, while it appears to have a $\alpha$-helical conformation in the $\mathrm{N}$-terminal, the rest of the molecule being $\beta$-sheet-rich.

The purified enzyme retained its original activity during a $120 \mathrm{~h}$ incubation period at 40 and $50^{\circ} \mathrm{C}$ (Figure 6). More than $85 \%$ of the original activity was retained after 120 hours at $60^{\circ} \mathrm{C}$, while residual activity was decreased to $73 \%$ after $120 \mathrm{~h}$ at $70^{\circ} \mathrm{C}$. At the higher temperatures tested, $80^{\circ} \mathrm{C}$ and $90^{\circ} \mathrm{C}$, the decrease of residual enzyme activity was sharp; it should be noted however that the enzyme 
maintained almost $30 \%$ of its original activity after $12 \mathrm{~h}$ incubation at $80^{\circ} \mathrm{C}$.

Whether there is a relationship between lower mass of an enzyme and higher thermostability is not clear. It has been observed in a number of cases that the two are related and it was suggested by several authors that a general tendency exists for enzymes with lower molecular masses to have higher thermostabilities [11,14,18,28]. For others however, certain structural features such as increased intramolecular packing or reduced surface loops that have prominent stabilizing effects are not usually related to protein size and therefore the hypothesis of a general tendency cannot be supported [12].

Primary structure analysis of the purified esterase as shown in Figure 4 , revealed a high degree of hydrophobic interactions in its molecule - a characteristic that is certainly related to higher thermostability [29-32]. A feature that appears in Figure 4 is the reduced surface area, since positive values represent amino acids that are likely to be exposed on the surface of the protein [27]. This feature also is in agreement with increased thermal stability of the esterase [29]. Another characteristic of the molecule of the isolated esterase that is in agreement with known

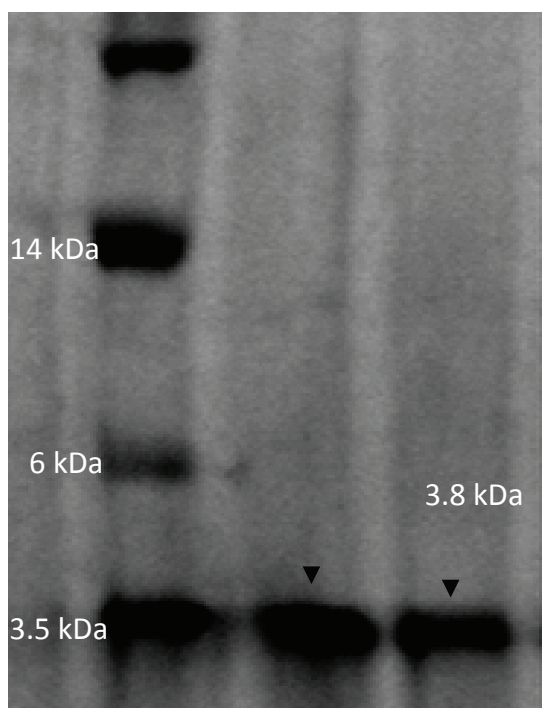

Figure 3: SDS-PAGE (16.5\%) of the purified esterase from B. subtilis NCIMB 8054.

Line 1: MW markers; Lines 2 and 3: esterase

\begin{tabular}{|l|c|c|}
\hline Amino acid & Number of residues & $\%$ \\
\hline Alanine & 3 & 8.8 \\
\hline Aspartic acid & 1 & 2.9 \\
\hline Glutamic acid & 3 & 8.8 \\
\hline Phenylalanine & 3 & 8.8 \\
\hline Histidine & 3 & 8.8 \\
\hline Isoleucine & 2 & 5.9 \\
\hline Proline & 5 & 14.7 \\
\hline Glycine & 1 & 2.9 \\
\hline Serine & 5 & 14.7 \\
\hline Threonine & 3 & 8.8 \\
\hline Valine & 2 & 5.9 \\
\hline Tyrosine & 3 & 8.8 \\
\hline
\end{tabular}

Table 1: Amino acid composition of the B. subtilis esterase.

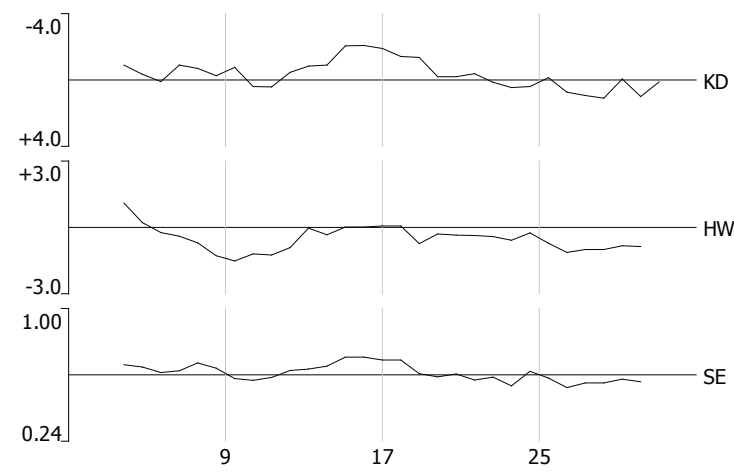

Figure 4: Plots of values calculated according to Kyte and Doolittle (KD) [25], Hopp and Woods (HW)[26] and Janin et al. [27] routines for the B. subtilis esterase. KD values fall within a range of +4 to -4 , with hydrophilic residues having a negative score. $\mathrm{HW}$ values fall within a range of -3 to +3 , with hydrophilic residues having a positive score. On the surface exposure (SE) graph peak values which fall above the axis line are predicted to be exposed on the surface of the protein.

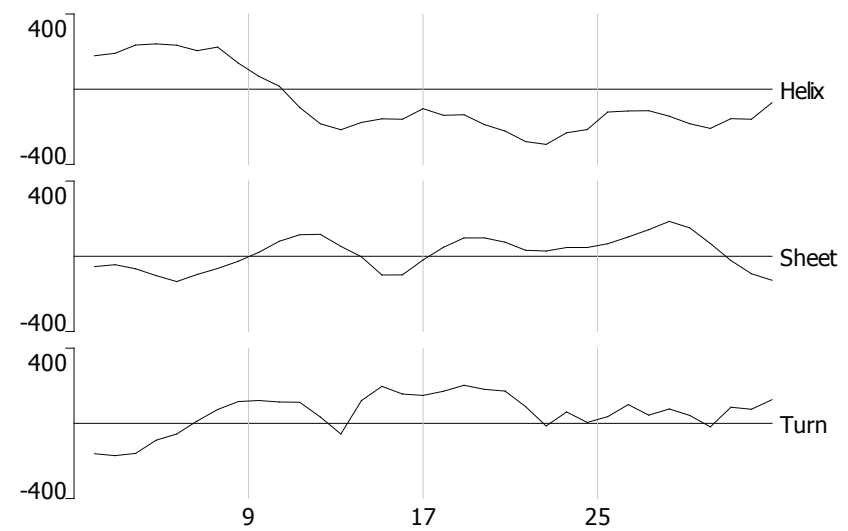

Figure 5: Garnier-Osguthorpe-Robson plots of the predicted values for $\alpha$-helix, $\beta$-sheet and $\beta$-turn configurations for the $B$. subtilis esterase. Values above the axis line represent regions which are likely to form helix sheet or turn structures.

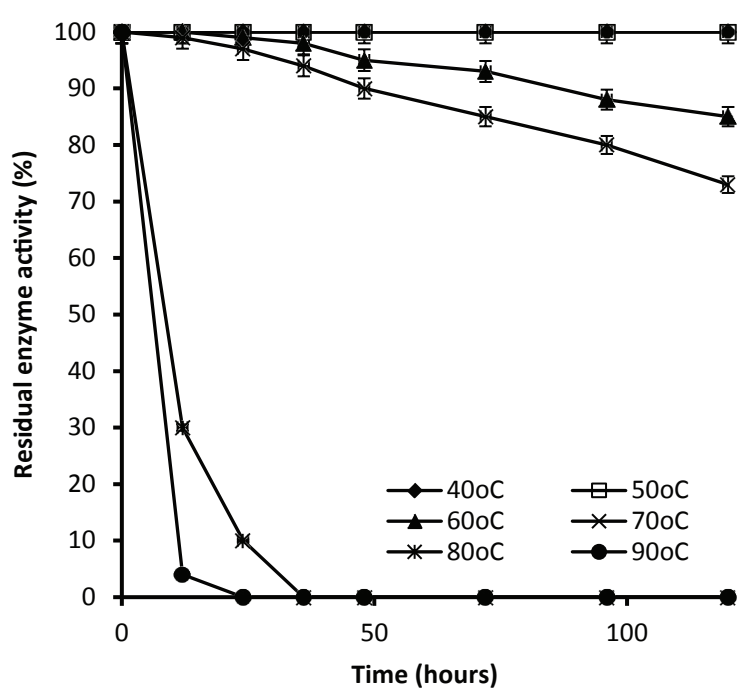

Figure 6: Residual esterase activity following incubation at various temperatures. 
Citation: Maria P, Emmanuel MP (2017) Purification, Amino Acid Sequencing and Thermostability of an Extracellular Low Molecular Weight Esterase Produced by Bacillus subtilis Nrrl 41270 in Fermentation. J Microb Biochem Technol 9:117-121. doi: 10.4172/1948-5948.1000353

characteristics of thermostable proteins is the high proline content and the absence of proline residues in the $\alpha$-helix area [31].

\section{Conclusion}

An overview of the literature data on small natural enzymes with less than $10 \mathrm{kDa}$ molecular weight gives only a few cases of isolated micro enzymes for which critical information, e.g. structure-related data, is not provided. Here we report results on the purification, sequencing and partial structural characterization of a thermostable low molecular weight esterase produced in fermentation by a $B$. subtilis strain. The results revealed a $3.85 \mathrm{kDa}$ and 34 amino acids protein, rich in proline and highly hydrophobic which also showed significant thermostability. Small biocatalysts could be versatile tools in biotechnology studies and may have various industrial applications. The present study shows that the micro esterase is secreted by B. subtilis and its molecule has interesting and rather rare characteristics. Further studies therefore, on the molecule itself and the producer microorganism in fermentations, are needed to highlight the production potential of the newly isolated esterase.

\section{References}

1. Van Dijl JM, Hecker M (2013) Bacillus subtilis: From soil bacterium to supersecreting cell factory. Microbial Cell Fact 12: 3

2. Schallmey M, Singh A, Ward OP (2004) Developments in the use of Bacillus species for industrial production. Can J Microbiol 50: 1-17.

3. Nicolas P, Mäder U, Dervyn E, Rochat T, Leduc A, Pigeonneau N, et al. (2012) Condition-dependent transcriptome reveals high-level regulatory architecture in Bacillus subtilis. Science 335: 1103-1106.

4. Dalbey RE, Wang P, van Dijl JM (2012) Membrane proteases in the bacterial protein secretion and quality control pathway. Microbiol Mol Biol Rev 76: $311-$ 330.

5. Westers L, Westers H, Quax WJ (2004) Bacillus subtilis as cell factory for pharmaceutical proteins: A biotechnological approach to optimize the host organism. Biochim Biophys Acta Mol Cell Res 1694: 299-310.

6. Amaki Y, Edgard ET, Ueda S, Ohmiya K, Yamane T (1992) Purification and properties of a thermostable esterase of Bacillus stearothermophilus produced by recombinant Bacillus brevis. Biosc Biotechnol Biochem 56: 238-241.

7. Schmidt M, Henke E, Heinz B, Kourist R, Hidalgo A, Bornscheuer UT (2007) A versatile esterase from Bacillus subtilis: Cloning, expression characterization and its application in biocatalysis. Biotechnol J 2: 249-253.

8. Torres S, Martínez MA, Pandey A, Castro GR (2009) An organic-solventtolerant esterase from thermophilic Bacillus licheniformis S-86. Biores Technol 100: 896-902.

9. Kanjanavas $\mathrm{P}$, Khuchareontaworn $\mathrm{S}$, Khawsak $\mathrm{P}$, Pakpitcharoen $\mathrm{A}$, et al (2010) Purification and characterization of organic solvent and detergent tolerant lipase from thermotolerant Bacillus sp. RN2. Int J Mol Sci 11: 37833792.

10. Wang J, Min C, Zheng G (2010) An intracellular esterase from Bacillus cereus catalyzing hydrolysis of 1-chloro-3-(1-napthyloxy)-2-acetoxypropanol. Ann Microbiol 60: 59-64.

11. Simoes DCM, McNeil D, Kristiansen B, Mattey M (1997) Purification and partial characterization of a $1.57 \mathrm{kDa}$ thermostable esterase from Bacillus stearothermophilus. FEMS Microbiol Lett 14: 7151-7156.

12. Monti D, Riva S (2001) Natural and artificial microenzymes: Is it possible to have small and efficient biocatalysts? Biocat Biotranf 19: 251-266

13. NCBI.

14. Simoes DCM, McNeil D, Kristiansen B, Mattey M (1995) Extracellular esterase activity from Bacillus stearothermophilus. Biotechnol Lett 17: 953-958.
15. Adoga G, Mattey M (1979) Properties of an extracellular peptide with esterase activity produced by Candida lipolytica. FEMS Microbiol Lett 6: 61-63.

16. Laxer S, Pinsky A, Bartoov B (1981) Further purification and characterization of a thermophilic rennet. Biotechnol Bioeng 23: 2483-2492.

17. Guagliardi A, Cerchia L, De Rosa M, Rossi M, Bartolucci S (1992) Isolation of a thermostable enzyme catalyzing disulfide bond formation from archaobacterium Sulfolobus solfataricus. FEBS Lett 303: 27-30.

18. Steele BD, Fiske MJ, Steele BP, Kelley VC (1992) Production of a low molecular-weight, alkaline-active, thermostable protease by a novel spiralshaped bacterium Kurthia spiroforme sp. Nov. Enzyme Microbial Technol 14 358-360.

19. Xiaolin F, Mattey M (1999) Small enzymes with esterase activities from two thermophilic fungi Emericella nidulans and Talaromyces emersonii. Biotechno Lett 21: 1071-1076.

20. Kramer DN, Guibault GG (1963) A substrate for the fluorometric determination of lipase activity. Anal Chem 35: 588-589.

21. Guibault GG, Kramer DN (1964) Fluorometric determination of lipase, amylase, alpha- and gamma-chymotrypsin and inhibitors of these enzymes. Anal Chem 36: $409-412$

22. Lowry OH, Rosebrough NJ, Farr AL, Randall RJ (1951) Protein measurement with the Folin phenol reagent. J Biol Chem 193: 265-275.

23. Komatsu S (2009) Western blotting/Edman sequencing using PVDF membrane Methods Mol Biol 536: 163-171.

24. Garnier J, Osguthorpe DJ, Robson B (1978) Analysis of the accuracy and implications of simple methods for predicting the secondary structure of globular proteins. J Mol Biol 120: 97-120.

25. Kyte J, Doolittle RF (1982) A simple method for displaying the hydropathic character of a protein. J Mol Biol 157: 105-132.

26. Hopp TP, Woods KR (1982) Prediction of protein antigenic determinants from amino acid sequences. Proc Natl Acad Sci USA 78: 3824-3828.

27. Janin J, Wodak S, Levitt M, Maigret B (1978) Conformation of amino acid sidechains in proteins. J Mol Biol 125: 357-386.

28. Tambe SM, Kaklij GS, Kelkar SM, Parekh LJ (1994) Two distinct molecular forms of phytase from Klebsiella aerogenes: Evidence for unusually smal active enzyme peptide. J Ferm Bioeng 77: 23-27.

29. Sterner R, Liebl W (2001) Thermophilic adaptation of proteins. Crit Rev Biochem Mol Biol 36: 39-106.

30. Kim T, Joo JC, Yoo YJ (2012) Hydrophobic interaction network analysis for thermostabilization of a mesophilic xylanase. J Biotechnol 161: 49-59.

31. Wijma HJ, Floor RJ, Janssen DB (2013) Structure- and sequence-analysis inspired engineering of proteins for enhanced thermostability. Curr Opin Struct Biol 23:588-594.

32. Li PY, Chen XL, Peng J, Li CY, Wang P, Zhang Y, et al. (2015) Inter-domain hydrophobic interactions modulate the thermostability of microbial esterases from the hormone-sensitive lipase family. J Biol Chem 290: 11188-11198. 